\title{
EKSTRAKSI MINYAK ATSIRI DARI KULIT JERUK SEBAGAI BAHAN TAMBAHAN PADA PEMBUATAN SABUN
}

\author{
Yustinah ${ }^{1)}$, Dena Fanandara ${ }^{1)}$ \\ 1) Teknik Kimia Fakultas Teknik Univesitas Muhammadiyah Jakarta \\ yustinah@ftumj.ac.id
}

\begin{abstract}
Orange is one of the tropical fruits that are produced in Indonesia. Many beverage industry using citrus fruits as raw materials, resulting in waste generated quite a lot, one of them orange peel waste. The research objective is memanfaatan waste orange peel is not consumed, thereby increasing the economic value of the waste. Early stage research, orange peel cut into small pieces, then weigh as much as 300 grams of orange peel and then dissolved in ethanol. The extraction process is done with constant stirring of $500 \mathrm{rpm}$ for 3 hours with a variable number of solvent of $300 \mathrm{ml}, 350 \mathrm{ml}, 400 \mathrm{ml}, 450 \mathrm{ml}$ and $500 \mathrm{ml}$. Extraction is then filtered by passing on anhydrous Na2SO4 and the filtrate was taken. Subsequently, the filtrate is heated using a vacuum evaporator at $60^{\circ} \mathrm{C}$ until all the ethanol evaporates. Having obtained the essential oil, then continued the process of making soap with essential oil obtained as an additive. This research resulted in the essential oils contained in the optimum amount of solvent to $500 \mathrm{ml}, 2.3432$ grams and the lowest amount of solvent $300 \mathrm{ml}, 1.4145 \mathrm{gram}$. GC-MS analysis of the obtained compound limonene contained in the volatile oil at the time of 7.01 minutes per cent area of $96.79 \%$. The test results hedonic on the texture and aroma of the soap which has been added the essential oil can be accepted by the panelists.
\end{abstract}

Keywords: ethanol, orange peel, essential oils, soaps

ABSTRAK. Jeruk adalah salah satu buah-buahan tropis yang banyak dihasilkan di Indonesia. Industri minuman banyak menggunakan buah jeruk sebagai bahan baku, sehingga mengakibatkan limbah yang dihasilkan jumlahnya cukup banyak, salah satunya limbah kulit jeruk. Tujuan penelitian adalah memanfaatan limbah kulit jeruk yang tidak dikonsumsi, sehingga akan meningkatkan nilai ekonomi limbah tersebut. Tahap penelitian mula-mula, kulit jeruk dipotong-potong kecil-kecil, kemudian timbang kulit jeruk sebanyak 300 gram lalu dilarutkan dalam etanol. Proses ekstraksi dilakukan dengan pengadukan konstan 500 rpm selama 3 jam dengan variabel jumlah pelarut sebanyak 300 ml, 350 ml, $400 \mathrm{ml}, 450 \mathrm{ml}$ dan $500 \mathrm{ml}$. Hasil ekstraksi kemudian disaring dengan melewatkannya pada $\mathrm{Na}_{2} \mathrm{SO}_{4}$ anhidrat dan filtratnya diambil. Selanjutnya,filtrat dipanaskan menggunakan vacum evaporator pada suhu $60^{\circ} \mathrm{C}$ sampai semua etanol menguap. Setelah diperoleh minyak atsiri, maka dilanjutkan proses pembuatan sabun dengan minyak atsiri yang didapat sebagai zat tambahan. Penelitian ini menghasilkan minyak atsiri yang optimum terdapat pada jumlah pelarut $500 \mathrm{ml}$ sebanyak 2,3432 gram dan terendah pada jumlah pelarut $300 \mathrm{ml}$ sebanyak 1,4145 gram. Dari analisa GC-MS didapatkan senyawa limonen yang terdapat dalam minyak atsiri pada waktu 7,01 menit dengan persen area sebesar 96,79\%. Hasil pengujian hedonik terhadap tekstur dan aroma sabun yang sudah ditambah minyak atsiri dapat diterima oleh para panelis.

Kata kunci: etanol, kulit jeruk, minyak atsiri, sabun 


\section{PENDAHULUAN}

Tanaman jeruk sudah tumbuh di Indonesia sejak ratusan tahun yang lalu, baik tumbuh secara alami maupun dibudidayakan. Tanaman buah jeruk yang ada di Indonesia adalah peninggalan bangsa Belanda, yang telah mendatangkan jeruk keprok dan jeruk manis dari Itali dan Amerika. Jeruk merupakan buah yang banyak mengandung zat gizi, vitamin dan mineral. Menurut hasil penelitian jeruk dapat bermanfaat mencegah berbagai penyakit seperti, penyakit kanker dan penyakit stroke. Sayangnya, selama ini jeruk terkenal hanya merupakan sumber vitamin C. Padahal, buah jeruk ini juga mengandung berbagai zat gizi esensial lainnya, yang meliputi : karbohidrat (serat makanan dan zat gula), kalium, magnesium, tembaga, kalsium, fosfor, folat, thiamin, niacin, riboflavin, vitamin $B_{6}$, asam pantotenat, dan senyawa fitokimia.

Menurut Albrigo dan Carter (1977), dalam Mauliyah, N.H, (2006) buah jeruk jika dilihat dari bagian luar ke arah dalam, mempunyai bagian-bagian utama : kulit, segmen-segmen dan core. Kulit jeruk tersusun atas bagian epidermis, flavedo, kelenjar minyak, dan bagian paling dalam ikatan pembuluh. Bagian segmen-segmen jeruk,terdiri dari dinding segmen, rongga cairan dan biji jeruk. Sedangkan core jeruk adalah bagian tengah yang terdiri dari ikatan pembuluh dan jaringan parenkim.

Pembuatan produk minuman sari buah jeruk, akan menghasilkan limbah yang berupa kulit jeruk, ampas dan biji jeruk. Saat ini limbah tersebut hanya digunakan sebagai pakan ternak atau hanya dibuang sebagai limbah industri.

Untuk meningkatkan nilai ekonomis limbah kulit jeruk danmeningkatkan pendapatan petani jeruk maka perlu dikajipemanfaatan limbah kulit jeruk sebagai bahan baku minyak atsiri. Menurut hasil penelitian Safaatul, M dan Prima, A. (2010) kulit jeruk manis dapat menghasilkan minyak atsiri. "Minyak atsiri" merupakan istilah yang digunakan untuk minyak bersifat mudah menguap, yangterdiri dari campuran beberapa zat dengan komposisi dan titik didih yang berbeda. Minyak ini terdapat di dalam kelenjar minyak yang harus dikeluarkan sebelum dilakukan penyulingan, yaitu dengan memotong kecil-kecil / menghancurkan jaringan pada tanaman dan membuka kelenjar minyak sebanyak mungkin, sehingga mengakibatkan minyak dapat dengan mudah diuapkan pada saat penyulingan (Suryaningrum, 2009). Minyak atsiri banyak digunakan dalam industri, misalnya industri sabun dan kosmetika sebagai pemberi aromadan rasa (flavor). Harga jual dari minyak atsiri ditentukan oleh kualitas minyak dan jumlah kadar komponen utamanya.

Teknik yang dapat digunakan untuk memperoleh minyak atsiri ada beberapa proses, yaitu dengan proses : pengepresan, penyulingan, ekstraksi pelarut, maserasi dan enfleurasi (Guenther 1987).

Proses ekstraksi adalah melarutkan minyak atsiri dalam bahan dengan menggunakan pelarut organik yang bersifat mudah menguap. Ekstraksi umumnya dapat dilakukan dalam tempat yang disebut "extractor". Ekstraksi menggunakan pelarut organik biasanya digunakan untuk mengekstraksi minyak atsiri yang mudah rusak karena pemanasan dengan uap dan air,misalnya untuk mengekstrak minyak atsiri dari bunga-bungaan misalnya bunga melati, mawar, cempaka, kenanga, lily, dan lainlain. Pelarut yang digunakan dalam proses ekstraksi yaitu: alkohol, petroleum eter, dan benzene (Guenther, 1987).

Pelarut yang digunakan dalam proses ekstraksi mempunyai syarat sebagai berikut (Guenther, 1987):

1. Pelarut bersifat selektif, yaitu dapat melarutkan semua zat wangi bunga dengan sempurna dan cepat, serta sedikit mungkin melarutkan bahan lilin dan pigmen.

2. Pelarut mempunyai titik didih yang cukup rendah, sehingga pelarut mudah diuapkan kembali tanpa menggunakan suhu tinggi.

3. Pelarut tidak bersifat larut dalam air. 
4. Pelarut harus bersifat inert, sehinggapelarut tidak bereaksi dengan komponen minyakbunga.

5. Pelarut mempunyai titik didih yang seragam, sehingga jika diuapkan tidak akantertinggal dalam minyak yang diperoleh.

6. Harga pelarut harus semurahmungkin,dan tidak mudah terbakar.

Proses ekstraksi dalam penelitian ini menggunakan pelarut Etanol. Etil alkohol atau disebut juga Etanol merupakan senyawa organik dengan rumus molekul $\mathrm{C}_{2} \mathrm{H}_{5} \mathrm{OH}$. Pada kondisi kamar, etanol berwujud cairan yang bersifat mudah menguap, mudah terbakar, tak berwarna.

Proses perlakuan pendahuluan terhadap bahan yang mengandung minyak atsiri dapat dilakukan dengan beberapa metode yaitu : dengan pengecilan ukuran bahan dan pengeringan atau pelayuan (Ketaren, 1985).

Proses pengecilan ukuran bahan dan pengeringan bahan mengandung minyak yang bersifat permiabel (mudah ditembus oleh zat cair dan uap), dilakukan dengan tujuan supaya dapat mengekstraksi minyak atsiri dalam waktu yang lebih singkat. Sebelum bahan tersebut dilakukan proses ekstraksi sebaiknya bahan dirajang terlebih dahulu menjadi potongan-potongan kecil. Proses perajangan ini bertujuan supaya kelenjar minyak terbuka sebanyak mungkin, sehingga pada saat proses ekstraksi, penguapan minyak atsiri dari bahan baku menjadi cukup cepat. Pada waktu perajangan, akan terjadi penguapan komponen minyak yang bertitik didih rendah. Sehingga untuk mendapatkan rendemen dan mutu minyak yang baik, hasil tahap perajangan harus segera dilakukan ekstraksi (Ketaren,1985).

Tahap perlakuan pendahuluan dengan cara pengeringan bahan berguna untuk :mempercepat proses ekstraksi, memperbaiki mutu minyak yang diperoleh dan mengurangi kadar air yang terkandung dalam bahan. Tetapi selama pengeringan kemungkinan juga sebagian minyak akan hilang karena penguapan dan proses oksidasi oleh oksigen dari udara (Ketaren, 1985).

Penelitian ini bertujuan untuk mengekstraksi minyak atsiri dari limbah kulit jeruk. Selanjutnya minyak atsiri yang diperoleh, akan digunakan untuk tambahan pada pembuatan sabun. Pada pembuatan sabun, minyak atsiri berfungsi sebagai pemberi aroma. Sehingga diharapkan sabun yang dihasilkan lebih disukai .,

\section{METODOLOGI PENELITIAN}

\section{Bahan dan Alat}

Bahan-bahan yang digunakan dalam percobaan adalah : kulit jeruk, etanol, $\mathrm{Na}_{2} \mathrm{SO}_{4}$ anhidrat, minyak kelapa sawit, $\mathrm{NaOH}$, aquades

Alat-alat yang digunakan dalam penelitian adalah : satu set peralatan ekstraksi, vaccum evaporator, gunting, blender, corong, piala gelas, pengaduk, cetakan sabun.

\section{Metode Penelitian}

Prosedur penelitian sebagai berikut :

1. Kulit jeruk sejumlah $300 \mathrm{gr}$ yang sudah bersih dipotong-potong kecil, kemudian dihancurkan dengan blender.

2. Ditambahkan etanol teknis dengan variasi sebanyak 300, 350, 400, 450 dan $500 \mathrm{ml}$ ke dalam piala gelas.

3. Proses ekstraksi dilakukan dengan pengadukan konstan 500 rpm denganwaktu 3 jam

4. Hasil ekstraksi disaring dan dilewatkan pada $\mathrm{Na}_{2} \mathrm{SO}_{4}$ anhidrat kemudian filtratnya diambil.

5. Dipanaskan filtrat dengan vaccum evaporator pada suhu $60^{\circ} \mathrm{C}$ sampai etanol menguap semua. Kemudian minyak atsiri yang sudah diperoleh ditimbang.

6. Minyak atsiri yang didapatkan ditambahkan pada saat pembuatan sabun.

\section{Metode Analisis}

Hasil minyak atsiri yang diperoleh dilakukan identifikasi menggunakan alat GC MS. Sedangkan terhadap sabun yang dihasilkan, dilakukan Uji Hedonik. 


\section{HASIL DAN PEMBAHASAN}

\section{Identifikasi Minyak Atsiri}

Identifikasi minyak atsiri yang dihasilkan, dilakukan menggunakan GC-MS yaitu menunjukkan adanya kandungan senyawa limonen dalam minyak atsiri yang didapat. Sampel yang digunakan untuk analisa diambil pada variabel jumlah pelarut 500 $\mathrm{ml}$ sebanyak $1 \mathrm{ml}$. Hasil analisa yang didapat, terdapat senyawa limonen dengan rumus molekul $\mathrm{C}_{10} \mathrm{H}_{16}$ dalam minyak atsiri dari kulit jeruk dengan waktu retensi 7,01 menit dan dengan persen area sebesar $96,79 \%$, dapat dilihat pada Gambar 1. Pada hasil kromatogram GCMS, terdapat beberapa senyawa minor pada minyak atsiri kulit jeruk, senyawa yang muncul antara lain yaitu 4-Carene, Sabinene, beta-Pinene, dan delta carene. Senyawa-senyawa yang muncul tersebut adalah senyawa yang terdapat juga pada kulit jeruk tetapi ada pada jumlah yang sangat sedikit sedangkan yang mendominasi adalah senyawa limonen.

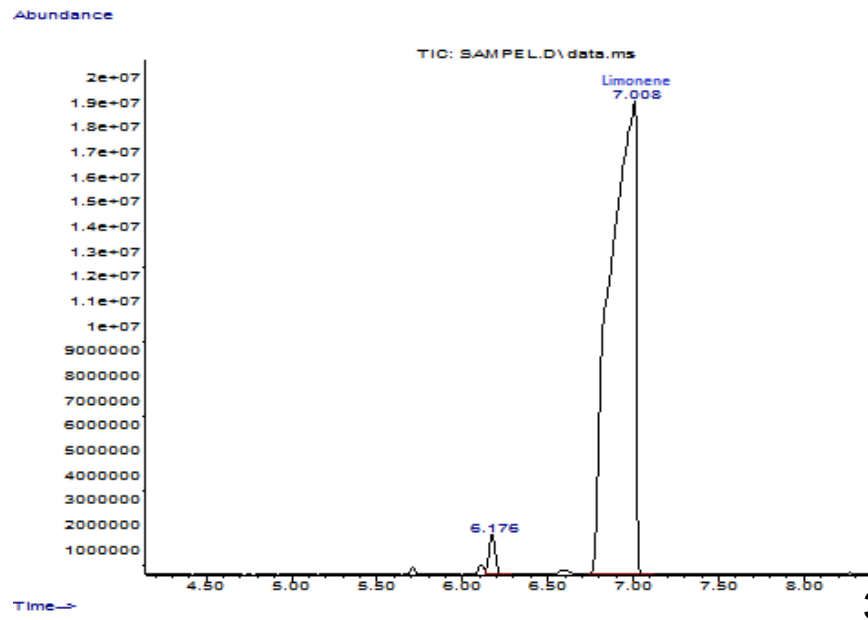

Gambar 1. Kromatogram GC-MS adanya kandungan limonene.

\section{Pengaruh Jumlah Pelarut terhadap Bobot Minyak}

Pada Gambar 2 menunjukkan bahwa bobot minyak atsiri yang paling banyak ditunjukkan pada jumlah pelarut sebesar $500 \mathrm{ml}$ yakni 2,3432 gram dan paling sedikit yakni pada jumlah pelarut sebesar $300 \mathrm{ml}$ dengan bobot 1,4145 gram. Kenaikan bobot minyak atsiri pada jumlah pelarut $350 \mathrm{ml}$ sebesar 1,5643 gram; pada $400 \mathrm{ml}$ sebesar 1,9824 gram; pada $450 \mathrm{ml}$ sebesar 2,2290 gram. Dari data tersebut, kondisi optimum terjadi pada jumlah pelarut $500 \mathrm{ml}$. Semua percobaan dilakukan dengan menggunakan sampel kulit jeruk sebanyak 300 gram dan lama waktu pengadukan selama 3 jam, dengan putaran 500 rpm. Dilihat dari grafik, semakin banyak pelarut yang digunakan, akan semakin banyak minyak atsiri yang diperoleh. Hal ini karena dengan jumlah molekul pelarut yang semakin besar, akan mengakibatkan jumlah molekul minyak yang terlarut juga semakin besar. Dan pada gambar 2 didapatkan persamaan linieritas $y=0,005 x-0,111$, dengan $y$ adalah bobot minyak atsiri yang diperoleh sedangan $x$ adalah jumlah pelarut yang digunakan dalam proses ekstraksi. Persamaan linieritas tersebut mempunyai nilai $R^{2}=0,9643$, sehingga dapat dinyatakan persamaan linier tersebut menunjukkan korelasi yang kuat antara variabel jumlah pelarut dan bobot minyak atsiri.

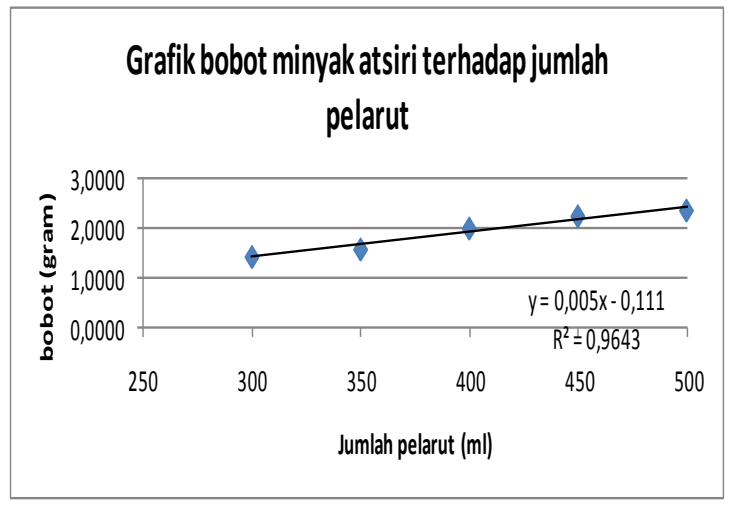

Gambar 2.Grafik hubungan antara bobot minyak atsiri terhadap jumlah pelarut.

\section{Uji HedonikTekstur Sabun}

Tabel 1.Uji Hedonik terhadap tekstur sabun

\begin{tabular}{|c|c|c|c|c|c|c|}
\hline \multirow{2}{*}{$\begin{array}{l}\text { Sampel } \\
\text { Sabun }\end{array}$} & \multicolumn{5}{|c|}{ Skala hedonik } & \multirow{2}{*}{$\begin{array}{c}\text { Rata- } \\
\text { rata }\end{array}$} \\
\hline & 1 & 2 & 3 & 4 & 5 & \\
\hline 142 & & 3 & 5 & 2 & & 2,9 \\
\hline 520 & & 2 & 6 & 2 & & 3,0 \\
\hline 445 & & 2 & 6 & 2 & & 3,0 \\
\hline
\end{tabular}

Pada tabel 1.menunjukkan skala hedonik dari panelis terhadap sampel berdasarkan tekstur. Rata-rata hasil dari 10 panelis 
menyatakan bahwa tekstur yang dihasilkan tertinggi yakni pada sampel sabun 520 dan 445, sabun yang ditambahkan 1 gram minyak atsiri dari variabel jumlah pelarut $350 \mathrm{ml}$ dan sabun yang ditambahkan 2 gram minyak atsiri dari variabel jumlah pelarut sebanyak 450 $\mathrm{ml}$, serta terendah yaitu pada sampel sabun 142, yaitu sampel sabun yang tidak ditambahkan minyak atsiri. Dari hasil uji hedonik menunjukkan skala hedonik dari panelis pada sampel 142 ke 520 mengalami kenaikan yang kurang signifikan dan statis pada sampel 445, yang disimpulkan bahwa penambahan minyak atsiri tidak memberi perubahan yang berarti pada tekstur sabun. Hasil rata-rata yang diperoleh dariskala hedonik terhadap tekstur adalah 3 yakni netral.

\section{Uji Hedonik Aroma Sabun}

Tabel 2.Uji Hedonik terhadap aroma

\begin{tabular}{|c|c|c|c|c|c|}
\hline \multirow{2}{*}{$\begin{array}{l}\text { Sampel } \\
\text { Sabun }\end{array}$} & \multicolumn{4}{|c|}{$\begin{array}{l}\text { sabun } \\
\text { Skala hedonik }\end{array}$} & \multirow{2}{*}{$\begin{array}{l}\text { Rata- } \\
\text { rata }\end{array}$} \\
\hline & 12 & $\frac{1 n e}{3}$ & $\frac{d o n}{4}$ & $\frac{1 K}{5}$ & \\
\hline 142 & 5 & 4 & 1 & & 2,6 \\
\hline 520 & & 2 & 4 & 4 & 42 \\
\hline 445 & & & 5 & 5 & 4.5 \\
\hline
\end{tabular}

Pada tabel 2. Menunjukkan skala hedonik dari panelis terhadap sampel berdasarkan aroma.Pada pengujian aroma yang dihasilkan diperoleh data tingkat kesukaan tertinggi pada sampel sabun 445 yaitu sabun yang ditambahkan 2 gram minyak atsiri dari variabel jumlah pelarut sebanyak $450 \mathrm{ml}$ dan terendah ada pada sampel sabun 142 yaitu sabun yang tidak ditambahkan minyak atsiri. Dari hasil uji hedonik menunjukkan skala hedonik dari tiap sabun mengalami peningkatan yang signifikan dan skala hedonik bertambah seiring dengan penambahan minyak atsiri. Hasil rata-rata dari skala hedonik terhadap aroma yang dihasilkan 4,2 4,5 yakni menyatakan suka.

\section{KESIMPULAN}

Minyak atsiri yang dihasilkan dari kulit jeruk berwarna sedikit kekuningan dan berbau khas seperti bau jeruk. Perolehan minyak atsiri yang paling banyak ditunjukkan pada jumlah pelarut $500 \mathrm{ml}$ yakni 2,3432 gram. Identifikasi menggunakan GC-MS diperoleh hasil adanya senyawa limonen dalam sampel minyak atsiri dari kulit jeruk pada waktu retensi 7,01 menit dan persen area sebesar 96,79\%.Pengujian terhadap tekstur dan aroma sabun yang sudah ditambah minyak atsiridapat diterima oleh para panelis.

\section{DAFTAR PUSTAKA}

Guenther, T. 1987. Minyak atsiri Jilid 1. UI Pers. Jakarta.

Ketaren, S. 1985.Pengantar Teknologi Minyak Atsiri. Balai Pustaka. Jakarta

Mauliyah, NH, 2006, Ekstraksi dan Karakterisasi Pektin dari Limbah Proses Pengolahan Jeruk Pontianak (Citrus nobilis var microcarpa), Departemen Teknologi Industri Pertanian,Fakultas Teknologi Pertanian,Institut Pertanian Bogor, Bogor

Safaatul, M dan Prima, A. 2010.Ekstraksi Minyak Daun Jeruk Purut(Citrus hystrix D.C.) Dengan Pelarut Etanol dan N-Heksana.Jurnal Kompetensi Teknik Vol. 2, No.1.

Suryaningrum, S. $2009 . \quad U j i$ AktivitasAntibakteri Minyak Atsiri Buah JerukPurut (Citrus hystrix D.C) terhadapStaphylococcus aureus danEscherichia coli. Fakultas Farmasi, Muhammadiyah Surakarta, Surakarta. 
